\title{
Aporphine alkaloids from Piper erecticaule and acetylcholinesterase inhibitory activity
}

[Alcaloides de aporfina obtenida de Piper erecticaule y actividad inhibitoria de la acetilcolinesterasa]

\author{
Wan Mohd Nuzul Hakimi Wan Salleh ${ }^{1}$, Norkamilah Abdullah ${ }^{1}$, Nur Athirah Hashim², \\ Heng Yen Khong ${ }^{3} \&$ Shamsul Khamis ${ }^{4}$ \\ ${ }^{1}$ Department of Chemistry, Faculty of Sciences and Mathematics, Universiti Pendidikan Sultan Idris (UPSI), Perak, Malaysia \\ ${ }^{2}$ Department of Chemistry, Faculty of Science, Universiti Teknologi Malaysia (UTM), Johor, Malaysia \\ ${ }^{3}$ School of Chemistry and Environment Studies, Faculty of Applied Sciences, Universiti Teknologi MARA (UiTM) Sarawak, Malaysia \\ ${ }^{4}$ School of Environmental and Natural Sciences, Faculty of Science and Technology, Universiti Kebangsaan Malaysia, Selangor, \\ Malaysia \\ Contactos | Contacts: Wan Mohd Nuzul Hakimi Wan SALLEH - E-mail address: wmnhakimi@ fsmt.upsi.edu.my
}

\begin{abstract}
Chemical constituents and biological activities of the aerial parts of Piper erecticaule C.DC. have been studied for the first time. Fractionation and purification of the extracts afforded aristolactam AII (1), aristolactam BII (2), piperolactam A (3), piperolactam C (4), piperolactam D (5), together with terpenoids of $\beta$-sitosterol, $\beta$-sitostenone, taraxerol, and lupeol. The structures of these compounds were obtained by analysis of their spectroscopic data, as well as the comparison with that of reported data. Acetylcholinesterase inhibitory activity revealed that compounds 1 and 3 showed strong AChE inhibitory effects with the percentage inhibition of $75.8 \%$ and $74.8 \%$, respectively.
\end{abstract}

Keywords: Piperaceae; Piper erecticaule; acetylcholinesterase; aporphine alkaloids; aristolactam

Resumen: Se estudiaron por primera vez los constituyentes químicos y actividad biológica de las partes aéreas de Piper erecticaule C.DC. El fraccionamiento y la purificación de los extractos proporcionaron aristolactama AII (1), aristolactama BII (2), piperolactama A (3), piperolactama C (4), piperolactama D (5), junto con terpenoides de $\beta$-sitosterol, $\beta$-sitostenona, taraxerol, y el lupeol. Las estructuras de estos compuestos se obtuvieron mediante el análisis de sus datos espectroscópicos, así como mediante la comparación con datos ya informados. La actividad inhibidora de la acetilcolinesterasa reveló que los compuestos 1 y 3 mostraron un potente efecto inhibidor de la AChE con un porcentaje de inhibición del $75.8 \%$ y $74.8 \%$, respectivamente.

Palabras clave: Piperaceae; Piper erecticaule; Acetilcolinesterasa; Alcaloides de aporfina; Aristolactama

Recibido | Received: May 4, 2019

Aceptado| Accepted: June 14, 2019

Aceptado en versión corregida | Accepted in revised form: July 5, 2019

Publicado en línea | Published online: September 30, 2019

Este artículo puede ser citado como / This article must be cited as: WMNHW Salleh, N Abdullah, NA Hashim, HY Khong, S Khamis. 2019 Aporphine alkaloids from Piper erecticaule and acetylcholinesterase inhibitory activity. Bol Latinoam Caribe Plant Med Aromat 18 (5): 527 - 532

Https://doi.org/10.35588/blacpma.19.18.5.35 


\section{INTRODUCTION}

Plants from the genus Piper have been used for a number of practical applications like remedies in many traditional medicinal systems such as traditional Chinese medicine, the Indian Ayurvedic system and folklore medicines of Latin America and West Indies (Parmar et al., 1997). The chemistry of Piper species has been widely investigated and the phytochemical investigations from all parts have led to the isolation of a number of pharmacologically active compounds. They have been extensively investigated as a source of new natural products with potential antitumoral, antimicrobial, antifungal and insecticidal activities (Kato \& Furlan, 2007).

$P$. erecticaule is commonly known as 'lada hutan', is a shrubby, woody herb. The leaves are rather thin, and chartaceous, the underside of which is glaucous (Tawan et al., 2002). The medicinal properties of this plant have not been studied. We have recently reported the chemical compositions and biological activities of the essential oils from this species (Salleh et al., 2014a). Analysis of $P$. erecticaule essential oils resulted in the identification of 35 chemical components, and the most abundant group components were sesquiterpene hydrocarbons (63.4\%). $\quad \beta$-Caryophyllene (5.7\%), spathulenol (5.1\%), $\beta$-cadinene $(3.8 \%)$ and $\alpha$-amorphene $(3.8 \%)$ were identified as their major components. The essential oils also displayed strong activity on Aspergillus niger with Minimum Inhibitory Concentration value of $31.3 \mu \mathrm{g} / \mathrm{mL}$. In addition, screening on the anticholinesterase activity of the leaves extract has also been reported. The $\mathrm{MeOH}$ extract of $P$. erecticaule showed good activity against butyrylcholinesterase enzyme with inhibition of $70.9 \%$ (Salleh et al., 2014b). In continuation of our phytochemical and bioactivity studies on this genus, herein we would like to report the detailed phytochemical study of $P$. erecticaule with their acetylcholinesterase inhibitory activity. To the best of our knowledge, there is no report on the constituents and bioactivity studies from this species.

\section{MATERIAL AND METHODS Plant material}

$P$. erecticaule was collected from Borneo and identified by Mohizar Mohamad. The voucher specimen (UiTMKS-02/2012) was deposited at the Applied Sciences Faculty, UiTM Sarawak.

\section{General experimental procedures}

Soxhlet extraction technique was applied to extract the phytochemicals from the dried sample using different polarity solvents ( $n$-hexane, ethyl acetate, and methanol). Vacuum liquid chromatography (VLC) was performed on Merck silica gel 60 (230400 mesh) while column chromatography (CC) on Merck silica gel 60 (70-230 mesh) as the stationary phase. Thin layer chromatography (TLC) analysis was performed on Merck pre-coated silica $\left(\mathrm{SiO}_{2}\right)$ gel F254 plates ( $0.2 \mathrm{~mm}$ thickness) to detect and monitor the presence of compounds in the samples. The spots were visualized under UV light at 254 and $365 \mathrm{~nm}$, included with spraying reagent vanillin-sulphuric acid in $\mathrm{MeOH}$ followed by heating. Melting points were measured using melting point apparatus equipped with a microscope, Leica Gallen III and were uncorrected. The ${ }^{1} \mathrm{H}(400 \mathrm{MHz})$ and ${ }^{13} \mathrm{C}$ NMR $(100 \mathrm{MHz})$ spectra were recorded on a Bruker Avance 400 Spectrophotometer. Chemical shifts were reported in ppm and $\mathrm{CDCl}_{3}$ as the solvent. Residual solvent was used as an internal standard. The IR spectra were recorded on Perkin Elmer ATR and 1600 spectrophotometer series as $\mathrm{KBr}$ disc. Mass spectral data were obtained from Mass Spectrometry Service, National University of Singapore (NUS), Singapore.

\section{Solvents and chemicals}

Analytical grade $n$-hexane, diethyl ether, ethyl acetate, chloroform, dichloromethane and methanol used for extraction and isolation were purchased from Merck (Germany). Acetylcholinesterase enzyme (Type-VI-S, EC3.1.1.7), acetylthiocholine iodide, 5,5'-dithio-bis (2-nitrobenzoic) acid (DTNB), and galantamine were purchased from Sigma-Aldrich (Germany).

\section{Extraction and isolation}

The dried and powdered aerial part of $P$. erecticaule (1 kg) was extracted successively by Soxhlet extractor with $n$-hexane, EtOAc and $\mathrm{MeOH}$. Evaporation of the respective solvents gave hexane $(5.0 \mathrm{~g})$, EtOAc $(9.2 \mathrm{~g})$ and $\mathrm{MeOH}(9.5 \mathrm{~g})$ extracts. The hexane extract was subjected to vacuum liquid chromatography (VLC) on $\mathrm{SiO}_{2} 60$ (230-400 mesh) using $n$-hexane and $\mathrm{CHCl}_{3}$ in $5 \%$ increasing polarity to give 8 fractions (PEH1-8). The combined fractions of PEH1-3 were purified by column chromatography on silica gel 70-230 mesh to afford $\beta$-sitosterol ( $n$ - 
hexane: $\left.\mathrm{CHCl}_{3}, \quad 70: 30\right)$ and $\beta$-sitostenone (nhexane: $\left.\mathrm{CHCl}_{3}, 60: 40\right)$. The crude EtOAc was fractionated by VLC on $\mathrm{SiO}_{2} 70-230$ mesh, using $n$ hexane and EtOAc in 10\% increasing polarity to give 15 fractions (PEE1-15). The combined fractions PEE2-5 were purified and recrystallized from hexane: $\mathrm{CHCl}_{3}$ to yield compounds 1 (nhexane: $\left.\mathrm{CHCl}_{3}, 50: 50\right)$ and $\mathbf{2}$ (n-hexane: $\mathrm{CHCl}_{3}$, 45:55). The combined fractions PEE6-8 were purified and recrystallized from hexane: $\mathrm{CHCl}_{3}$ to yield compounds 3 ( $n$-hexane: $\mathrm{CHCl}_{3}, 40: 60$ ), taraxerol ( $n$ hexane: $\mathrm{CHCl}_{3}, 70: 30$ ), and lupeol ( $n$-hexane: $\mathrm{CHCl}_{3}$, 60:40). The crude $\mathrm{MeOH}$ was fractionated by VLC on $\mathrm{SiO}_{2} 70-230$ mesh, using $\mathrm{CHCl}_{3}: \mathrm{MeOH}$ in $10 \%$ increasing polarity to give fractions (PEM1-5). The combined fractions PEE2-3 were purified by column chromatography to yield compounds 4 (nhexane: $\left.\mathrm{CHCl}_{3}, 20: 80\right)$ and $\mathbf{5}$ (n-hexane: $\mathrm{CHCl}_{3}$, 25:75).

\section{Acetylcholinesterase activity}

AChE inhibitory activities were measured by slightly modifying the spectrophotometric method (Salleh et al., 2014b). Electric eel AChE were used, while acetylthiocholine iodides were employed as substrates of the reaction. 5,5'-Dithio-bis(2nitrobenzoic) acid (DTNB) was used for the measurement of the AChE activity. Briefly, $140 \mu \mathrm{L}$ of sodium phosphate buffer ( $\mathrm{pH} 8.0$ ), $20 \mu \mathrm{L}$ of DTNB, $20 \mu \mathrm{L}$ of the compound (concentration of 1 $\mathrm{mg} / \mathrm{mL}$ ) and $20 \mu \mathrm{L}$ of $\mathrm{AChE}$ solution were added by multichannel automatic pipette in a 96-well microplate and incubated for $15 \mathrm{~min}$ at $25^{\circ} \mathrm{C}$. The reaction was then initiated with the addition of $10 \mu \mathrm{L}$ of acetylthiocholine iodide. Hydrolysis of acetylthiocholine iodide was monitored by the formation of the yellow 5-thio-2-nitrobenzoate anion as a result of the reaction of DTNB with thiocholines, catalyzed by enzymes at $412 \mathrm{~nm}$ utilizing a 96 -well microplate reader (Epoch Micro-Volume Spectrophotometer). Percentage inhibition (I\%) of AChE was determined by comparison of reaction rates of samples relative to blank sample (ethanol in phosphate buffer $\mathrm{pH}=8$ ) using the formula:

$$
I \%=[E-S / E] \times 100 ;
$$

where $\mathrm{E}$ is the activity of enzyme without test sample and $S$ is the activity of enzyme with test sample.
Galantamine was used as a reference. Analyses were run in triplicate and the result was expressed as means \pm SD of triplicate. Data obtained from the acetylcholinesterase activity are expressed as mean values. Statistical analyses were carried out by employing one way ANOVA $(p>0.05)$. A statistical package (SPSS version 11.0) was used for the data analysis.

\section{RESULTS AND DISCUSSION}

Phytochemical studies on the aerial parts of $P$. erecticaule species which has led to the isolation of nine compounds, which characterized as five aporphine alkaloids, two triterpenes, and two steroids. These metabolites were identified by analyzing their spectroscopic data and comparing with the literature data. Five aporphine alkaloids elucidated as aristolactam AII (1), aristolactam BII (2), piperolactam A (3), piperolactam C (4), piperolactam D (5), together with terpenoids of $\beta$ sitosterol, $\beta$-sitostenone, taraxerol, and lupeol. Aporphine alkaloids broadly exist in nature and have a distinctive biological activity. Many of these isolated aporphine alkaloids were isolated previously from Piper genus. Compound (1) and (2) have been isolated from $P$. officinarum (Salleh et al., 2014c) and $P$. betle (Lin et al., 2013), whilst the compound (3), (4), and (5) have been isolated from $P$. betle (Amin et al., 2017), P. taiwanense (Chen et al., 2004), and $P$. nigrum (Ee et al., 2008), respectively. The isolated terpenoids were also reported most of the Piper species. They were readily identified by comparison of physical and spectroscopic data and mass spectrometry data with values found in the literature (Salleh et al., 2016a; Salleh et al., 2016b).

Aristolactams, which also found in this species is a minor group of fused phenanthrene lactam alkaloids structurally and biogenetically related to aporphines (Michle et al., 2014). The richest source of this class of alkaloids is undoubtedly plants of the family Piperaceae and Aristolochiaceae (Tsai et al., 2005; Levrier et al., 2013). Aristolactams are frequently used as folk medicines in several countries. Meanwhile, these molecules show an interesting array of biological properties such as anti-inflammatory, antiplatelet, anti-mycobacterial, neuroprotective and anti-cancer activities (Kumar et al., 2003; Kim et al., 2004; Zhang et al., 2007). 
<smiles>[R]c1c([R])c([R])c2c3c(cc4ccccc42)NC(=O)c13</smiles>

(1) $\mathrm{R}_{1}=\mathrm{H} ; \mathrm{R}_{2}=\mathrm{OH} ; \mathrm{R}_{3}=\mathrm{OCH}_{3}$

(2) $\mathrm{R}_{1}=\mathrm{H} ; \mathrm{R}_{2}=\mathrm{R}_{3}=\mathrm{OCH}_{3}$

(3) $\mathrm{R}_{1}=\mathrm{H} ; \mathrm{R}_{2}=\mathrm{OCH}_{3} ; \mathrm{R}_{3}=\mathrm{OH}$

(4) $\mathrm{R}_{1}=\mathrm{R}_{2}=\mathrm{R}_{3}=\mathrm{OCH}_{3}$

(5) $\mathrm{R}_{1}=\mathrm{R}_{2}=\mathrm{OCH}_{3} ; \mathrm{R}_{3}=\mathrm{OH}$

Figure $\mathbf{N}^{\circ} 1$

Aporphine alkaloids from $P$. erecticaule

Aristolactam AII (1) - Pale yellow needles (5.0 mg,); m.p. $269-272^{\circ} \mathrm{C}$; IR ( $\left.\mathrm{KBr}\right) v_{\max } \mathrm{cm}^{-1}$ : 3335 , 2918, 1717, 1597, 1498; ${ }^{1} \mathrm{H}$ NMR $\left(\mathrm{CDCl}_{3}, 400\right.$ $\mathrm{MHz}): \delta_{\mathrm{H}} 4.11\left(3 \mathrm{H}, \mathrm{s}, 4-\mathrm{OCH}_{3}\right), 7.16(1 \mathrm{H}, \mathrm{s}, \mathrm{H}-9)$, $7.59(2 \mathrm{H}$, ddd, $J=7.2,7.2,2.0 \mathrm{~Hz}, \mathrm{H}-6$ and $\mathrm{H}-7), 7.92$ $(1 \mathrm{H}, \mathrm{dd}, J=6.8,2.0 \mathrm{~Hz}, \mathrm{H}-8), 7.71(1 \mathrm{H}, \mathrm{s}, \mathrm{H}-2), 9.77$ $(1 \mathrm{H}$, br.s, N-H), $9.20(1 \mathrm{H}, \mathrm{dd}, J=6.8,2.0 \mathrm{~Hz}, \mathrm{H}-5)$; ${ }^{13} \mathrm{C} \mathrm{NMR}\left(\mathrm{CDCl}_{3}, 100 \mathrm{MHz}\right): \delta_{\mathrm{C}} 56.8(4-\mathrm{OCH} 3)$, 104.3 (C-9), 107.9 (C-2), 124.9 (C-1a/4a), 126.7 (C7/8), 127.9 (C-5/6), 128.5 (C-4b/9b), 134.7 (C-8a), 135.3 (C-9a), 148.1 (C-4), 149.1 (C-3), 168.6 (C-1); EIMS $m / z 265\left[\mathrm{M}^{+}, \mathrm{C}_{16} \mathrm{H}_{11} \mathrm{NO}_{3}\right]$ (Salleh et al., 2014c).

Aristolactam BII (2) - Yellow powder (8.0 mg), m.p. $260-262^{\circ} \mathrm{C}$; IR (KBr) $v_{\max } \mathrm{cm}^{-1}: 3336,2920$, $1715,1597,1495 ;{ }^{1} \mathrm{H}$ NMR $\left(\mathrm{CDCl}_{3}, 400 \mathrm{MHz}\right): \delta_{\mathrm{H}}$ $4.03\left(3 \mathrm{H}, \mathrm{s}, 4-\mathrm{OCH}_{3}\right), 4.12\left(3 \mathrm{H}, \mathrm{s}, 3-\mathrm{OCH}_{3}\right), 7.13$ $(1 \mathrm{H}, \mathrm{s}, \mathrm{H}-9), 7.56(2 \mathrm{H}, \mathrm{m}, \mathrm{H}-6$ and $\mathrm{H}-7), 7.85(1 \mathrm{H}, \mathrm{s}$, $\mathrm{H}-2), 7.94(1 \mathrm{H}, \mathrm{m}, \mathrm{H}-8), 9.11(1 \mathrm{H}, \mathrm{m}, \mathrm{H}-5), 10.83$ $(1 \mathrm{H}$, br s, $\mathrm{NH}) ;{ }^{13} \mathrm{C} \mathrm{NMR}\left(\mathrm{CDCl}_{3}, 100 \mathrm{MHz}\right): \delta_{\mathrm{C}} 60.3$ (4-OCH3), 60.6 (3-OCH3), 105.7 (C-9), 114.3 (C-2), 121.0 (C-4a), 124.3 (C-1a), 126.1 (C-7/8), 127.7 (C9b), 129.2 (C-5/6), 131.0 (C-4b), 132.3 (C-8a), 134.4 (C-9a), 146.5 (C-4), 157.9 (C-3), $\delta 173.9$ (C-1); EIMS $m / z 279\left[\mathrm{M}^{+}, \mathrm{C}_{17} \mathrm{H}_{13} \mathrm{NO}_{3}\right]$ (Salleh et al., 2014c).

Piperolactam A (3) - Yellowish needle crystals (10 mg); m.p. $300-301{ }^{\circ} \mathrm{C}$; IR (KBr) $v_{\max } \mathrm{cm}^{-1}: 3475$, $3185,1656,1500,1445 ;{ }^{1} \mathrm{H}$ NMR $\left(\mathrm{CDCl}_{3}, 400\right.$ $\mathrm{MHz}): \delta_{\mathrm{H}} 4.10\left(3 \mathrm{H}, \mathrm{s}, \mathrm{OCH}_{3}\right), 7.15(1 \mathrm{H}, \mathrm{s}, \mathrm{H}-9), 7.25$ $(1 \mathrm{H}, \mathrm{m}, \mathrm{H}-7), 7.55$ (1H, m, H-6), $7.75(1 \mathrm{H}, \mathrm{s}, \mathrm{H}-2)$, 7.85 (1H, m, H-8), $9.30(1 \mathrm{H}, \mathrm{m}, \mathrm{H}-5), 9.85(1 \mathrm{H}$, br.s, $\mathrm{NH}) ;{ }^{13} \mathrm{C}$ NMR $\left(\mathrm{CDCl}_{3}, 100 \mathrm{MHz}\right): \delta_{\mathrm{C}} 57.5$ $\left.\mathrm{OCH}_{3}\right), 107.0(\mathrm{C}-9), 108.5(\mathrm{C}-2), 116.1(\mathrm{C}-4 \mathrm{a}), 116.5$ (C-1), 126.5 (C-10a), 126.5 (C-6), 127.5 (C-7), 128.5 (C-4b), 129.0 (C-5), 129.5 (C-8), 135.8 (C-8a), 135.8
(C-10), 149.7.2 (C-3), $151.5(\mathrm{C}-4), 172.2(\mathrm{C}=\mathrm{O})$; EIMS $m / z 265\left[\mathrm{M}^{+}, \mathrm{C}_{16} \mathrm{H}_{11} \mathrm{NO}_{3}\right]$ (Amin et al., 2017).

Piperolactam C (4) - Yellow crystalline crystals (5.0 mg); m.p. $250-252^{\circ} \mathrm{C}$; IR (KBr) $v_{\max } \mathrm{cm}^{-1}: 3265$, $2928,1678,1615,1485 ;{ }^{1} \mathrm{H}$ NMR $\left(\mathrm{CDCl}_{3}, 400\right.$ $\mathrm{MHz}): \delta_{\mathrm{H}} 4.00\left(3 \mathrm{H}, \mathrm{s}, 4-\mathrm{OCH}_{3}\right), 4.20(3 \mathrm{H}, \mathrm{s}, 3-$ $\left.\mathrm{OCH}_{3}\right), 4.50\left(3 \mathrm{H}, \mathrm{s}, 2-\mathrm{OCH}_{3}\right), 7.83(1 \mathrm{H}, \mathrm{m}, \mathrm{H}-9)$, 7.50-7.55 (2H, m, H-6, H-7), $9.20(1 \mathrm{H}, \mathrm{m}, \mathrm{H}-5) ;{ }^{13} \mathrm{C}$ $\mathrm{NMR}\left(\mathrm{CDCl}_{3}, 100 \mathrm{MHz}\right): \delta_{\mathrm{C}} 60.5\left(4-\mathrm{OCH}_{3}\right), 61.5(3-$ $\left.\mathrm{OCH}_{3}\right), 63.2\left(2-\mathrm{OCH}_{3}\right), 106.0(\mathrm{C}-9), 116.8(\mathrm{C}-4 \mathrm{a})$, 125.6 (C-6), $126.5(\mathrm{C}-4 \mathrm{~b} / 5), 126.5$ (C-7), 128.6 (C8), 133.5 (C-8a), 146.8 (C-4), 154.8 (C-3), 157.1 (C2), $167.0(\mathrm{C}-1)$; EIMS m/z $309\left[\mathrm{M}^{+}, \mathrm{C}_{18} \mathrm{H}_{15} \mathrm{NO}_{4}\right]$ (Chen et al., 2004).

Piperolactam D (5) - Yellow crystalline solid (8.5 mg); m.p. $227-229^{\circ} \mathrm{C}$; IR (KBr) $v_{\max } \mathrm{cm}^{-1}$ : 3260, $2925,1675,1610,1482 ;{ }^{1} \mathrm{H}$ NMR $\left(\mathrm{CDCl}_{3}, 400\right.$ $\mathrm{MHz}): \delta_{\mathrm{H}} 3.92\left(3 \mathrm{H}, \mathrm{s}, 3-\mathrm{OCH}_{3}\right), 4.45(3 \mathrm{H}, \mathrm{s}, 4-$ $\left.\mathrm{OCH}_{3}\right), 7.25(1 \mathrm{H}, \mathrm{s}, \mathrm{H}-9), 7.49(2 \mathrm{H}, \mathrm{m}, \mathrm{H}-6, \mathrm{H}-7)$, $7.86(1 \mathrm{H}, \mathrm{m}, \mathrm{H}-8), 9.26$ (1H, m, H-5), $9.80(1 \mathrm{H}$, br.s, $\mathrm{NH}) ;{ }^{13} \mathrm{C}$ NMR $\left(\mathrm{CDCl}_{3}, 100 \mathrm{MHz}\right): \delta_{\mathrm{C}} 61.6$ (3$\left.\mathrm{OCH}_{3}\right), 62.5\left(4-\mathrm{OCH}_{3}\right), 105.5(\mathrm{C}-9), 106.5(\mathrm{C}-1)$, 112.0 (C-10a), 125.8 (C-7), 126.5 (C-6), 127.1 (C4a), 127.8 (C-5a), 127.2 (C-5), 129.0 (C-8), 134.1 (C9a), 135.6 (C-10), 140.2 (C-3), 153.5 (C-4), 154.6 (C-2), $167.2(\mathrm{C}=\mathrm{O})$; EIMS m/z $295\left[\mathrm{M}^{+}, \mathrm{C}_{17} \mathrm{H}_{13} \mathrm{NO}_{4}\right]$ (Ee et al., 2008).

Acetylcholine (AChE) is recognized as the most important neurotransmitter, have been studied for their inhibitory action on the progression of Alzheimer disease as they improve the cognitive function (Park, 2010). Previous studies revealed that most of the aporphine alkaloids exhibit acetylcholinesterase (AChE) inhibitory effects (Loizzo et al., 2008). Thus, the AChE inhibitory 
activities of compounds 1-5 were measured by slightly modifying the spectrophotometric method (Salleh et al., 2014b). It was compared with that of galantamine, as a standard drug against Alzheimer's disease and the results were shown in Table 1 . The results revealed that compounds $\mathbf{1}$ and $\mathbf{3}$ showed strong AChE inhibitory effects with the percentage inhibition of $75.8 \%$ and $74.8 \%$, respectively.
Galanthamine was used as a standard, which exhibited $85.5 \%$ inhibition of AChE. By comparing the structure-activity relationship of compounds 1 and $\mathbf{3}$, the hydroxyl at $\mathrm{C}-2$ and $\mathrm{C}-3$ position might play important roles in AChE inhibitory activity of aporphine alkaloids. Other exhibited potent AChE inhibitory activity with the percentage inhibition values ranging from $60.1-65.2 \%$.

Table $\mathbf{N}^{\circ} 1$

Acetylcholinesterase inhibitory activity of aporphine alkaloids from $P$. erecticaule

\begin{tabular}{|l|c|}
\hline Samples & AChE inhibition (I\%) \\
\hline Aristolactam AII (1) & $75.5 \%$ \\
\hline Aristolactam BII (2) & $62.5 \%$ \\
\hline Piperolactam A (3) & $74.8 \%$ \\
\hline Piperolactam C (4) & $60.1 \%$ \\
\hline Piperolactam D (5) & $65.2 \%$ \\
\hline Galantamine & $85.5 \%$ \\
\hline
\end{tabular}

\section{CONCLUSION}

The present study is the first to report that aporphine alkaloids were isolated from $P$. erecticaule, which have much chemotaxonomic importance within the genus Piper. Additionally, compound 1 showed the highest inhibition among others, may be of interest to clarify the physiological role of this enzyme. In addition, to validate the above-mentioned activity, clinical trials should be carried out in order to ensure safe use of the compounds as therapeutic agents against neurodegenerative diseases such as Alzheimer. This study also provides valuable and useful information and indications for further exploring the potential nutraceutical and pharmaceutical applications of the Lauraceae species.

\section{ACKNOWLEDGMENTS}

The authors would like to thank the University Research Grant (GPU) for financial support under vote 2018-0208-108-01 and the Department of Chemistry, Faculty of Science and Mathematics, Universiti Pendidikan Sultan Idris for research facilities.

\section{REFERENCES}

Amin SA, Bhattacharya P, Basak S, Gayen S, Nandy A, Saha, A. 2017. Pharmacoinformatics study of Piperolactam A from Piper betle root as the new lead for nonsteroidal anti fertility drug development. Comput Biol Chem 67: $213-224$.

https://doi.org/10.1016/j.compbiolchem.2017.01 .004

Chen Y, Chen JC, Chang Y, Teng C, Lin W, Wu C, Chen, I. 2004. A new aristolactam alkaloid and anti-platelet aggregation constituents from Piper taiwanense. Planta Med 70: 174 $-177$. https://doi.org/10.1055/s-2004-815497

Ee GCL, Lim SK, Lim CM, Dzulkefly K. 2008. Alkaloids and carboxylic acids from Piper nigrum. Asian J Chem 20: 5931 - 5940.

Kato MJ, Furlan M. 2007. Chemistry and evolution of Piperaceae. Pure Appl Chem 79: 529 538. https://doi.org/10.1351/pac200779040529

Kim SR, Sung SH, Kang SY, Koo KA, Kim SH, Ma CJ, Lee HS, Park MJ, Kim YC. 2004. Aristolactam BII of Saururus chinensis attenuates glutamate-induced neurotoxicity in rat cortical cultures probably by inhibiting nitric oxide production. Planta Med 70: 391 $-396$.

https://doi.org/10.1055/s-2004-818964 
Kumar V, Poonam, Prasad AK, Parmar VS. 2003. Naturally occurring aristolactams, aristolochic acids, and dioxoaporphines and their biological activities. Nat Prod Rep 20: 565 - 583. https://doi.org/10.1039/b303648k

Levrier C, Balastrier M, Beattie KD, Carroll AR, Martin F, Choomuenwai V, Davis RA. 2013. Pyridocoumarin, aristolactam, and aporphine alkaloids from the Australian rainforest plant Goniothalamus australis. Phytochemistry 86: 121 - 126.

https://doi.org/10.1016/j.phytochem.2012.09.01 9

Lin CF, Hwang TL, Chien CC, Tu HY, Lay HL. 2013. A new hydroxychavicol dimer from the roots of Piper betle. Molecules 18: 2563 2570.

https://doi.org/10.3390/molecules18032563

Loizzo MR, Tundis R, Menichini F. Menichini F. 2008. Natural products and their derivatives as cholinesterase inhibitors in the treatment of neurodegenerative disorders: an update. Curr Med Chem 15: 1209 - 1228. https://doi.org/10.2174/092986708784310422

Michle J, Ingrouille MJ, Simmonds MSJ, Heinrich M. 2014. Naturally occurring aristolochic acid analogues and their toxicities. Nat Prod Rep 31: $676-693$. https://doi.org/10.1039/c3np70114j

Park SY. 2010. Potential therapeutic agents against Alzheimer's disease from natural sources. Arch Pharm Res 33: 1589 - 1609. https://doi.org/10.1007/s12272-010-1010-y

Parmar VS, Jain SC, Bisht KS, Jain R, Taneja P, Jha A, Tyagi OD, Prasad AK, Wengel J, Olsen CE, Boll PM. 1997. Phytochemistry of the genus Piper. Phytochemistry 46: 597 - 673. https://doi.org/10.1016/S0031-9422(97)00328-2

Salleh WMNHW, Ahmad F, Khong HY. 2014a. Chemical compositions and antimicrobial activity of the essential oils of Piper abbreviatum, $P$. erecticaule and $P$. lanatum (Piperaceae). Nat Prod Comm 9: 1795 1798.
Salleh WMNHW, Hashim NA, Ahmad F, Khong HY. 2014b. Anticholinesterase and antityrosinase activities of ten Piper species from Malaysia. Adv Pharm Bull 4: 527 531. https://doi.org/10.5681/apb.2014.078

Salleh WMNHW, Ahmad F, Khong HY. 2014c. Antioxidant and anti-tyrosinase activities from Piper officinarum C.DC (Piperaceae). J Appl Pharm Sci 4: 87 - 91. https://doi.org/10.7324/JAPS.2014.40516

Salleh WMNHW, Ahmad F, Khong HY, Zulkifli RM, Chen JJ, Nahar L, Wansi JD, Sarker SD. 2016a. Beilschglabrines A and B: Two new bioactive phenanthrene alkaloids from the stem bark of Beilschmiedia glabra. Phytochem Lett 16: 192 - 196. https://doi.org/10.1016/j.phytol.2016.04.013

Salleh WMNHW, Ahmad F, Khong HY, Zulkifli RM, Sarker SD. 2016b. Madangones A and B: Two new neolignans from the stem bark of Beilschmiedia madang and their bioactivities. Phytochem Lett 15: 168 - 173. https://doi.org/10.1016/j.phytol.2016.01.004

Tawan CS, Ipor IB, Fasihuddin BA, Sani H. 2002. A brief account on the wild Piper (Piperaceae) of the Crocker Range, Sabah. ASEAN Review of Biodiversity and Environmental Conservation (ARBEC), Universiti Malaysia Sarawak.

Tsai IL, Lee FP, Wu CC, Duh CY, Ishikawa T, Chen JJ, Chen YC, Seki H, Chen IS. 2005. New cytotoxic cyclobutanoid amides, a new furanoid lignan and anti-platelet aggregation constituents from Piper arborescens. Planta Med 71: 535 - 542. https://doi.org/10.1055/s-2005-864155

Zhang YN, Zhong XG, Zheng ZP, Hu XD, Zuo JP, Hu LH. 2007. Discovery and synthesis of new immunosuppressive alkaloids from the stem of Fissistigma oldhamii (Hemsl.) Merr. Bioorg Med Chem 15: 988 - 996. https://doi.org/10.1016/j.bmc.2006.10.034 